\section{BRAZIULIAN JOURNAL}

OF MEDICAL AND BIOLOGICAL RESFARCH

www.bjournal.com.br
ISSN 0100-879X

Volume 43 (8) 698-811 August 2010

BIOMEDICAL SCIENCES

AND

CLINICAL INVESTIGATION

Braz J Med Biol Res, August 2010, Volume 43(8) 717-721

doi: 10.1590/S0100-879X2010007500068

Cytogenetic characterization and evaluation of $c-M Y C$ gene amplification in PG100, a new Brazilian gastric cancer cell line

H.F. Ribeiro, D.F.A. Alcântara, L.A. Matos, J.M.C. Sousa, M.F. Leal, M.A.C. Smith, R.R. Burbano and M.O. Bahia

The Brazilian Journal of Medical and Biological Research is partially financed by
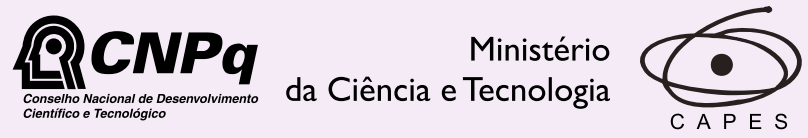

Ministério da Educação

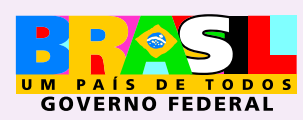

DFAPESP

Institutional Sponsors
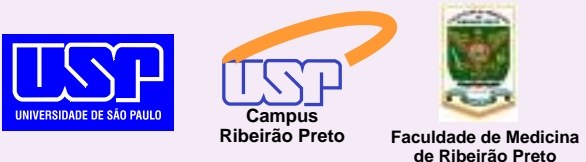

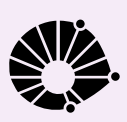

UNICAMP
Ф SHIMADZU

GE Healthcare
Hotsite of proteomics metabolomics developped by:

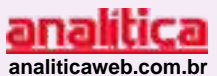

Thermo
SCIEN TIFIC 


\title{
Cytogenetic characterization and evaluation of c-MYC gene amplification in PG100, a new Brazilian gastric cancer cell line
}

\author{
H.F. Ribeiro ${ }^{1}$, D.F.A. Alcântara ${ }^{1}$, L.A. Matos ${ }^{1}$, J.M.C. Sousa1 ${ }^{1}$, M.F. Leal², \\ M.A.C. Smith ${ }^{2}$, R.R. Burbano ${ }^{1}$ and M.O. Bahia ${ }^{1}$ \\ ${ }^{1}$ Laboratório de Citogenética Humana, Instituto de Ciências Biológicas, \\ Universidade Federal do Pará, Belém, PA, Brasil \\ ${ }^{2}$ Disciplina de Genética, Universidade Federal de São Paulo, São Paulo, SP, Brasil
}

\begin{abstract}
Gastric cancer is the fourth most frequent type of cancer and the second cause of cancer mortality worldwide. The genetic alterations described so far for gastric carcinomas include amplifications and mutations of the c-ERBB2, KRAS, MET, TP53, and c-MYC genes. Chromosomal instability described for gastric cancer includes gains and losses of whole chromosomes or parts of them and these events might lead to oncogene overexpression, showing the need for a better understanding of the cytogenetic aspects of this neoplasia. Very few gastric carcinoma cell lines have been isolated. The establishment and characterization of the biological properties of gastric cancer cell lines is a powerful tool to gather information about the evolution of this malignancy, and also to test new therapeutic approaches. The present study characterized cytogenetically PG100, the first commercially available gastric cancer cell line derived from a Brazilian patient who had a gastric adenocarcinoma, using GTG banding and fluorescent in situ hybridization to determine MYC amplification. Twenty metaphases were karyotyped; 19 (95\%) of them presented chromosome 8 trisomy, where the MYC gene is located, and 17 (85\%) presented a deletion in the 17p region, where the TP53 is located. These are common findings for gastric carcinomas, validating PG100 as an experimental model for this neoplasia. Eighty-six percent of 200 cells analyzed by fluorescent in situ hybridization presented MYC overexpression. Less frequent findings, such as $5 p$ deletions and trisomy 16, open new perspectives for the study of this tumor.
\end{abstract}

Key words: Carcinogenesis; Chromosomal abnormalities; Gastric cancer; Oncogenes

\section{Introduction}

Gastric cancer (GC) is currently the fourth neoplasia in incidence and the second in mortality, and approximately $90 \%$ of GC are classified as adenocarcinomas (1). The development and progression of GC involves alterations in oncogenes and tumor suppressor genes, as well as other mechanisms that control genomic stability. Alterations described so far include amplifications and mutations in the c-ERBB2, KRAS, MET, TP53, and c-MYC genes $(2,3)$. The chromosomal instability described for GC, represented by gains and losses of whole chromosomes or parts of them, shows the need for a better understanding of the cytogenetic aspects of this neoplasia. For this purpose, the use of cell lines is a powerful tool (3).

Chromosome 8 abnormalities are frequent in many solid tumors and hematopoietic proliferations $(4,5)$. The c-MYC gene is located in this chromosome at the $8 \mathrm{q} 24.1$ band, coding a nuclear phosphoprotein whose impact is noticed in approximately $15 \%$ of the genome (6). This gene is a very important regulator of cellular proliferation, differentiation and growth, and of the apoptosis process, having, therefore, an important function in genome regulation. Deregulation of this gene is cited as one of the main events in cancer pathogenesis. Recent studies have implicated the MYC oncoprotein as a genomic instability mediator since it induces reactive oxygen species (ROS), causing aneuploidies (7). Overexpression of this gene has been found in approximately $40 \%$ of gastric malignancies (8).

The establishment and characterization of GC cell lines has been used to gather information about the evolution of this malignancy, and a large bank of well-characterized cell lines could reflect the diversity of tumoral phenotypes, provid-

Correspondence: M.O. Bahia, Laboratório de Citogenética Humana, Instituto de Ciências Biológicas, Universidade Federal do Pará, 66075-110 Belém, PA, Brasil. E-mail: mbahia@ufpa.br

Received January 11, 2010. Accepted July 5, 2010. Available online July 23, 2010. Published August 13, 2010. 
ing useful models for the study of this neoplasia. Nevertheless, few cell lines originated from gastric tumors are available, and most of them are from Asia (4). Our research group characterized the first GC cell line in Brazil, called ACP01, and recently established and characterized three new GC cell lines $(4,9)$.

The objective of the present communication is to report the cytogenetic characterization of the first commercially available Brazilian gastric cancer cell line, PG100, derived from the GC of a Brazilian patient and obtained commercially. The line was characterized using GTG banding and complemented with evaluation of the MYC gene amplification via fluorescent in situ hybridization (FISH).

\section{Material and Methods}

\section{PG100 cell line}

The PG100 cell line was obtained from Rio de Janeiro Cell Bank, Brazil (10). This cell line was established from

Table 1. Karyotype of 20 PG100 cell line metaphases analyzed.

\begin{tabular}{|c|c|}
\hline Cell & Karyotype \\
\hline 1 & $\begin{array}{l}59, \mathrm{XXY},+5,+8,+9,+10,+11,+13,+14,+15, \operatorname{del}(17)(p),+16 \\
+19,+21,+22\end{array}$ \\
\hline 2 & $47, X Y, \operatorname{del}(2)(p),+8$ \\
\hline 3 & $50, X Y,-4,+8,+13,+15, \operatorname{del}(17)(p),+19,+20$ \\
\hline 4 & $55, \mathrm{XY},+6,+7,+8,+11,+11,+17, \operatorname{del}(17)(\mathrm{p}),+18,+21,+22$ \\
\hline 5 & $50, X Y,+8,+16,+17, \operatorname{del}(17)(p),+18$ \\
\hline 6 & $\begin{array}{l}52, \mathrm{XY}, \operatorname{del}(4)(\mathrm{p}), \operatorname{del}(5)(\mathrm{p}),+8,+10,+12,+16, \operatorname{del}(17)(\mathrm{p}),+19, \\
+20\end{array}$ \\
\hline 7 & $50, X Y, \operatorname{del}(5)(p),+8,+16,+17, \operatorname{del}(17)(p),+20, \operatorname{add}(22)(q)$ \\
\hline 8 & $55, \mathrm{XY},+8,+11,+15,+16,+17, \operatorname{del}(17)(p),+20,+20,+21,+22$ \\
\hline 9 & $\begin{array}{l}55, X Y,+5, \operatorname{del}(5)(p),+6,+7,+8, \operatorname{del}(12)(p),+14,+15, \operatorname{del}(17)(p) \\
+18,+20,+22\end{array}$ \\
\hline 10 & $43, Y,-X,+8, \operatorname{del}(17)(p),-18,-20,-21$ \\
\hline 11 & $\begin{array}{l}54, X Y, \operatorname{del}(3)(p),+4, \operatorname{del}(5)(p),+8,+17, \operatorname{del}(17)(p),+22, \\
\operatorname{add}(22)(q)[2],+M,+M,+M\end{array}$ \\
\hline 12 & $50, X Y, \operatorname{del}(5)(p),+8,+17, \operatorname{del}(17)(p)[2],+21,+22$ \\
\hline 13 & $\begin{array}{l}54, X Y, \operatorname{del}(5)(p),+8,+13,+17, \operatorname{del}(17)(p),+18,+19,+20,+20 \\
-21\end{array}$ \\
\hline 14 & $59, X Y,+8,+17, \operatorname{del}(17)(p),+10 d m i n s$ \\
\hline 15 & $\begin{array}{l}57, X Y,+8,+11,+12,+17, \operatorname{del}(17)(p),+19,+20,+20,+20 \\
+2 \text { dmins,+ring }\end{array}$ \\
\hline 16 & $\begin{array}{l}57, \mathrm{XY},+4,+5,+16,+17, \operatorname{del}(17)(\mathrm{p}),+18,+18,+19,+21,+22, \\
+22,+\mathrm{dmin}\end{array}$ \\
\hline 17 & $42, X Y,+5,+8,-10,+13,-14,-16,-20,+21,-22$ \\
\hline 18 & $45, X Y,-1,+3,-7,+8,+10,-14,-18,-20,+21$ \\
\hline 19 & $50, X Y,+8$, del $(17)(p),+3 d$ mins \\
\hline 20 & $57, X Y, \operatorname{del}(4 p),+8,+13,+16,+17, \operatorname{del}(17)(p)+7$ dmins \\
\hline $\begin{array}{l}\text { Composite } \\
\text { karyotype }\end{array}$ & $\begin{array}{l}43-59, \mathrm{XY},+4,+5, \operatorname{del}(5)(p),+6,+7,+8,+10,+11,+12,+13,+14 \\
+15,+16,+17, \operatorname{del}(17)(p),+18,+19,+20,-20,+21,+22\end{array}$ \\
\hline
\end{tabular}

a primary gastric adenocarcinoma of a 29-year-old Brazilian man. PG100 was cultured in $25-\mathrm{cm}^{2}$ culture flasks at $37^{\circ} \mathrm{C}$ in HAM-F10 medium plus Dulbecco's MEM medium (Sigma, USA) supplemented with $15 \%$ fetal calf serum and the antibiotics kanamicin $(0.1 \mathrm{mg} / \mathrm{mL})$, ciprofloxacin $(0.02$ $\mathrm{mg} / \mathrm{mL})$, streptomycin $(0.1 \mathrm{mg} / \mathrm{mL})$, and penicillin (99 U/ $\mathrm{mL}$ ) until they reached confluence, which occurred every $48 \mathrm{~h}$. For subculture, the cellular monolayer was washed using $5 \mathrm{~mL}$ Hanks solution $\left(0.4 \mathrm{~g} \mathrm{KCl}, 0.06 \mathrm{~g} \mathrm{KH}_{2} \mathrm{PO}_{4}\right.$, $0.04 \mathrm{~g} \mathrm{Na}_{2} \mathrm{HPO}_{4}, 0.35 \mathrm{~g} \mathrm{NaHCO}_{3}, 1 \mathrm{~g}$ glycose, $8 \mathrm{~g} \mathrm{NaCl}$, $1000 \mathrm{~mL} \mathrm{H}_{2} \mathrm{O}$ ) and harvested with trypsin ( $0.125 \mathrm{~g}$ porcine trypsin and $0.02 \mathrm{~g}$ EDTA diluted in $100 \mathrm{~mL}$ Hank's solution). Cell split ratio was 1:2 to 1:4 flasks. The PG100 cell line grew in a disorganized single layer of cells similar to fibroblasts.

\section{Conventional cytogenetic analysis}

Cytogenetic analysis was performed when the cell line was in the 8th passage. Briefly, exponentially growing cells were synchronized and blocked with $0.0016 \%$ colchicine. Cells were harvested with $0.05 \%$ trypsin, treated with hypotonic solution $(7.5 \mathrm{mM} \mathrm{KCl})$ for $2 \mathrm{~h}$ at $37^{\circ} \mathrm{C}$, and fixed with $3: 1$ methanol/acetic acid. Slides were banded using standard trypsin-Giemsa banding (GTG-banding). Chromosomes of 100 metaphase spreads were counted to determine the modal number and 20 metaphases were karyotyped. The description of chromosome aberrations was based on the recommendations of the International System for Human Cytogenetic Nomenclature (11).

\section{Fluorescence in situ hybridization analysis}

FISH was performed on freshly prepared slides from cells at the 8th passage fixed in methanol/acetic acid. Cells were hybridized with Repeat-Free ${ }^{\mathrm{TM}}$ Poseidon $^{\text {TM }}$ C-MYC (8q24) (KBI-10106, Kreatech Diagnostics, Netherlands) according to the manufacturer protocol. The nuclei were counterstained with DAPI/ antifade and 200 interphase nuclei were analyzed. Positive c-MYC signals appeared as fluorescent red spots in the nucleus.

\section{Results}

The PG100 cell line was defined as a hyperdiploid cell line with a modal number of 49 chromosomes. The chromosome number ranged from 33 to 96 in 100 metaphases analyzed and none of them presented a normal karyotype. An alteration was defined as clonal when it was present in two or more metaphases with the same additional chromosome or structural abnormality or three or more metaphases presenting the loss of a chromosome as recommended by Ref 11 . According to these criteria, 24 clonal alterations were found in this cell line. Table 1 shows the karyotypes of the 20 
metaphases analyzed, as well as the composite karyotype for this cell line. The most frequent alteration was chromosome 8 trisomy (19 cells/95\%) followed by deletion of region $17 p$ (17 cells/85\%), chromosome 17 trisomy (11 cells/55\%), chromosome 16 trisomy ( 7 cells/35\%), and region $5 p$ deletion ( 6 cells $/ 30 \%$ ). Double minutes were observed in $25 \%$ of cells. It is also important to note that pair 17 also presented chromatin despiralization in the centromeric region, impairing the recognition of this chromosome.

c-MYC amplification was evaluated by FISH. Of 200 cells analyzed, 149 presented three copies of c-MYC (74.5\%), but overall $c-M Y C$ superexpression ( $\geq 3$ positive signals) was observed in $86 \%$, since $9 \%$ (18 cells) presented four signals and $2.5 \%$ ( 5 cells) five or more signals. The highest number of signals found was eight. A karyotyped cell and an interphase nucleus presenting c-MYC trisomy are shown in Figure 1.

\section{A}

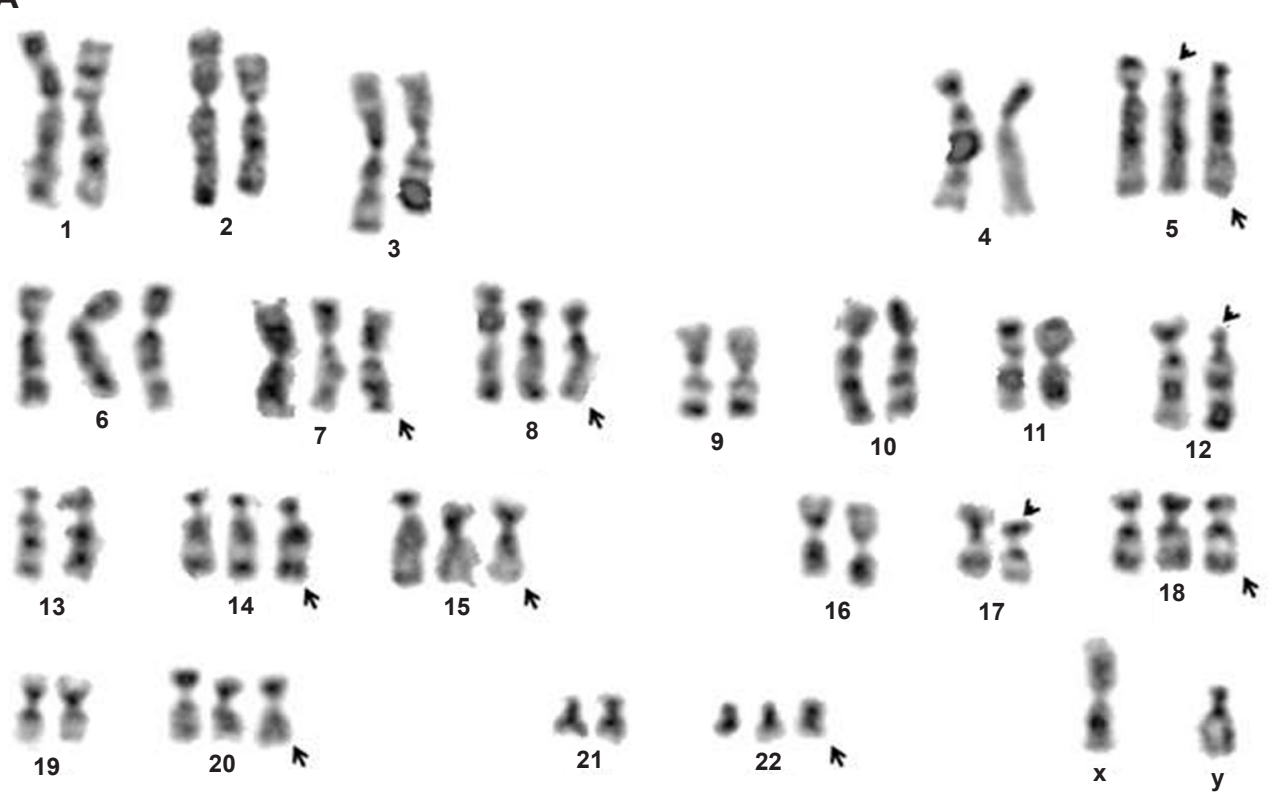

B

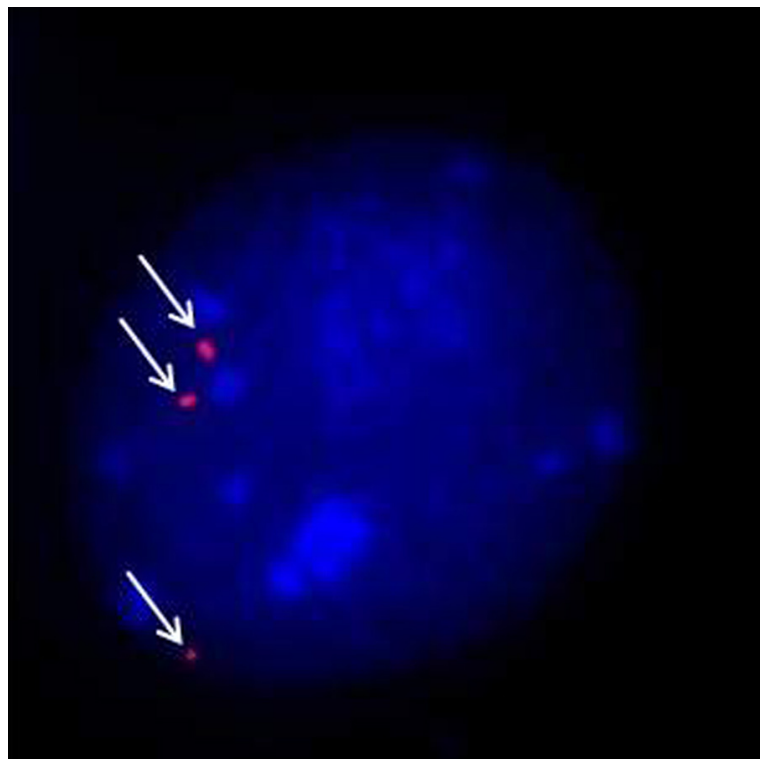

Figure 1. Cytogenetic analysis of the PG100 cell line. A, Karyogram of a GTG-banded metaphase. The arrows indicate trisomy of chromosomes 5,6 , $7,8,14,15,18,20$, and 22; the arrowheads indicate deletions in regions $5 p$, $12 p$ and $17 p$. B, Fluorescence in situ hybridization analysis of an interphase cell. The white arrows show fluorescent signals corresponding to three copies of MYC. 


\section{Discussion}

The cell line presented an extremely aneuploid karyotype, a complexity that makes the analysis of these alterations very difficult since cancer chromosomal aberrations are complex and hard to interpret, which is a classic difficulty in studies involving cytogenetic analysis of neoplasias. Different tumors show a wide range of various chromosomal gains and losses, raising questions about the specificity and the meaning of many of these changes (12).

Chromosomal instability is considered to have a key role in the generation of genetic and phenotypic alterations in cancer cells, being one of the two major genomic instability pathways involved in gastric carcinogenesis (13). Studies involving conventional cytogenetic techniques have revealed frequent amplifications at regions $1 \mathrm{q}, 2 \mathrm{q}, 3 \mathrm{q}, 6 \mathrm{q}$, $7 p, 7 q, 8 q, 13 q, 17 q, 20 p$, and $20 q$ and deletions at regions $1 p, 1 q, 2 p, 3 p, 4 q, 5 q, 6 p, 7 q, 9 p, 11 p, 11 q, 12 q, 15 q, 17 p$, $18 q, 19 p$, also including extra X chromosomes and 8, 9, or 19 trisomy (8).

Trisomy 8 was the most frequent abnormality found in PG100. Gains of chromosome 8, either trisomies or polysomies, are among the most common alterations found in malignant gastric tumors $(2,3)$ and in cell lines obtained from them, as previously described by our group in a population of Northern Brazil (14) and in four GC cell lines $(4,9)$. Overamplification of c-MYC was found in $86 \%$ of the PG100 cells analyzed by FISH, confirming previous findings.

$\mathrm{c}-\mathrm{MYC}$ codifies a protein that acts as the main regulator of many cellular processes, especially cell growth. Deregulation of MYC protein expression can promote DNA replication even in the presence of environmental limitations and in the absence of growth factors (15). Elevated MYC levels create a mutagenic environment in the cells by increasing ROS yield and also promoting p53 phosphorylation, an indicator of checkpoint activation induced by double-strand breaks. When MYC is activated, cells pass through the G1/S transition but undergo a p53-dependent G2 arrest, which is indicative of accumulation of DNA damage during or before the S phase (7). Even though the status of TP53 in this cell line is unknown, our results suggest that it might have lost at least one functional copy (as discussed below). Such loss could reduce TP53 cellular function, disrupting the $\mathrm{G} 2$ arrest caused by MYC-mediated genomic instability, and therefore the damages could accumulate, increasing the genetic alterations in this cell line.

Another common alteration in the PG100 cell line was the deletion of chromosome $17 p(85 \%)$, where the locus of TP53 gene is located, followed by chromosome 17 trisomy (55\%). Deletion of $17 p$ eliminates the locus of TP53, an important factor for carcinogenesis. The present study suggests that this gene has lost at least one of its functional alleles, which would impair its functions, especially those related to cell cycle arrest and DNA repair. Other studies also reported extra copies of chromosome 17 with deletion of $17 p$ in GC samples (16).

The PG100 cell line also presented trisomy 16 in 35\% of the cells analyzed. Although this trisomy is not among the most frequent cytogenetic findings in gastric tumors, it was previously observed in several GC samples (17), but little is known about the importance of this alteration in the gastric carcinogenesis process. The $16 q$ region contains putative tumor suppressor genes, including $\mathrm{CDH} 1$, that codes for E-cadherin, a crucial component of the adherence junctions between epithelial cells. Mutations in this gene are associated with a higher risk for hereditary diffuse-type GC and hereditary lobular breast cancer (18).

We also found a deletion in region $5 p$ in $30 \%$ of the metaphases analyzed. Alterations in this region have been reported, but they are not usual. Using the highresolution comparative genomic hybridization technique, our group previously reported this deletion in 3/24 diffuse-type GC (19). Many genes involved in important metabolic cell functions are located in the $5 p$ region, such as $D A B 2$, located at $5 p 13.1$, a putative tumor suppressor gene member of the Ras GTPase-activating family. Its down-regulation has been reported in several neoplasias, including colorectal cancer (20). The loss of $5 p$ in the PG100 cell line may lead to a down-expression of DAB2, along with other genes, that might play an important role in gastric carcinogenesis.

The data presented here suggest that the PG100 cell line shares the main genetic alterations found in GC, such as trisomy 8 and $17 p$ deletion, which justify the use of this cell line as a model to study GC. Our findings also support the notion that the MYC gene has a key role in GC due to the high frequency of its amplification. Even though our results corroborate many cytogenetic findings described elsewhere for GC, including the role of MYC in gastric carcinogenesis, other less frequent findings such as $5 p$ deletion and trisomy 16 open new perspectives for future studies concerning this specific neoplasia.

\section{Acknowledgments}

This study received financial support from the Brazilian government (CNPq/MCT/CNPq/CTBio/CTSaúde/MS/ SCTIE/DECIT Edital No. 20/2007 - BIOINOVA - Process No. 550885/2007-2). H.F. Ribeiro and D.F.A. Alcântara received Master's grants sponsored by CAPES. L.A. Matos and J.M.C. Sousa had CNPq Master's grants. M.F. Leal has a Ph.D. grant from FAPESP. 


\section{References}

1. Brenner $\mathrm{H}$, Rothenbacher $\mathrm{D}$, Arndt $\mathrm{V}$. Epidemiology of stomach cancer. Methods Mol Biol 2009; 472: 467-477.

2. Calcagno DQ, Leal MF, Seabra AD, Khayat AS, Chen ES, Demachki S, et al. Interrelationship between chromosome 8 aneuploidy, C-MYC amplification and increased expression in individuals from northern Brazil with gastric adenocarcinoma. World J Gastroenterol 2006; 12: 6207-6211.

3. Buffart TE, Carvalho B, Mons T, Reis RM, Moutinho C, Silva $P$, et al. DNA copy number profiles of gastric cancer precursor lesions. BMC Genomics 2007; 8: 345.

4. Lima EM, Rissino JD, Harada ML, Assumpcao PP, Demachki $S$, Guimaraes AC, et al. Conventional cytogenetic characterization of a new cell line, ACP01, established from a primary human gastric tumor. Braz J Med Biol Res 2004; 37: 18311838.

5. Calistus Jude AL, Sasikala K, Chandrasekar TS, Ashok Kumar R, Sudha S, Vimala Devi M, et al. Cytogenetic findings in cancerous and non-cancerous lesions of the digestive system. Int J Hum Genet 2005; 5: 199-203.

6. Fernandez PC, Frank SR, Wang L, Schroeder M, Liu S, Greene J, et al. Genomic targets of the human c-Myc protein. Genes Dev 2003; 17: 1115-1129.

7. Herold S, Herkert B, Eilers M. Facilitating replication under stress: an oncogenic function of MYC? Nat Rev Cancer 2009; 9: 441-444.

8. Panani AD. Cytogenetic and molecular aspects of gastric cancer: clinical implications. Cancer Lett 2008; 266: 99115.

9. Leal MF, Martins do Nascimento JL, da Silva CE, Vita Lamarao MF, Calcagno DQ, Khayat AS, et al. Establishment and conventional cytogenetic characterization of three gastric cancer cell lines. Cancer Genet Cytogenet 2009; 195: 8591.

10. Rio de Janeiro Cell Bank. http://www.nce.ufrj.br/bcrj/busca1. asp?bcrj=HP005. Accessed June 7, 2010.

11. Mitelman F. ISCN: An international system for human cytogenetics nomenclature. Basel: 2005.
12. Seizinger BR, Klinger HP, Junien $C$, Nakamura $Y$, Le Beau $\mathrm{M}$, Cavenee $\mathrm{W}$, et al. Report of the committee on chromosome and gene loss in human neoplasia. Cytogenet Cell Genet 1991; 58: 1080-1096.

13. Ottini L, Falchetti M, Lupi R, Rizzolo P, Agnese V, Colucci G, et al. Patterns of genomic instability in gastric cancer: clinical implications and perspectives. Ann Oncol 2006; 17 (Suppl 7): vii97-102.

14. Calcagno DQ, Leal MF, Taken SS, Assumpcao PP, Demachki $\mathrm{S}$, Smith MA, et al. Aneuploidy of chromosome 8 and C-MYC amplification in individuals from northern Brazil with gastric adenocarcinoma. Anticancer Res 2005; 25: 4069-4074.

15. Eilers M, Eisenman RN. Myc's broad reach. Genes Dev 2008; 22: 2755-2766.

16. Takahashi Y, Nagata T, Asai S, Shintaku K, Eguchi T, Ishii $Y$, et al. Detection of aberrations of $17 p$ and p53 gene in gastrointestinal cancers by dual (two-color) fluorescence in situ hybridization and GeneChip p53 assay. Cancer Genet Cytogenet 2000; 121: 38-43.

17. Stamouli MI, Ferti AD, Panani AD, Raftakis J, Consoli C, Raptis SA, et al. Application of multiplex fluorescence in situ hybridization in the cytogenetic analysis of primary gastric carcinoma. Cancer Genet Cytogenet 2002; 135: 23-27.

18. Kaurah P, MacMillan A, Boyd N, Senz J, De Luca A, Chun $\mathrm{N}$, et al. Founder and recurrent $\mathrm{CDH} 1$ mutations in families with hereditary diffuse gastric cancer. JAMA 2007; 297: 2360-2372.

19. Takeno SS, Leal MF, Lisboa LC, Lipay MV, Khayat AS, Assumpcao PP, et al. Genomic alterations in diffuse-type gastric cancer as shown by high-resolution comparative genomic hybridization. Cancer Genet Cytogenet 2009; 190: 1-7.

20. Kleeff J, Huang Y, Mok SC, Zimmermann A, Friess H, Buchler MW. Down-regulation of DOC-2 in colorectal cancer points to its role as a tumor suppressor in this malignancy. Dis Colon Rectum 2002; 45: 1242-1248. 